\title{
Effect of sequential presoaking and chlorine dioxide treatment on the inactivation of pathogenic Escherichia coli and Salmonella spp. on sprout seeds
}

\author{
Nguyen Bao Hung ${ }^{1,6}$, Woon-Ra Park', Bohyun Yun², Dong Cheol Seo ${ }^{3}$, Won-II Kim¹ , Hyun-Ju Kim4,
} Sanghyun $\mathrm{Han}^{5}$ and Se-Ri Kim${ }^{1 *}$ (1)

\begin{abstract}
This study was conducted to evaluate the effect of sequential presoaking and chlorine dioxide $\left(\mathrm{ClO}_{2}\right)$ on the reduction of pathogenic Escherichia coli and Salmonella spp. in alfalfa. When unsoaked and presoaked alfalfa were exposed to $200 \mathrm{ppm} \mathrm{ClO}_{2}$ for $15 \mathrm{~min}$, the population of E. coli and Salmonella spp. on presoaked seeds reduced more than those on unsoaked seeds by 2.07 and $1.43 \log C F U ~ g^{-1}(p<0.05)$, respectively. To determine the optimal concentration and treatment time to reduce pathogenic $E$. coli and Salmonella spp. in alfalfa seeds immersed in water for $5 \mathrm{~h}$, presoaked seeds were exposed to four different concentrations of $\mathrm{ClO}_{2}(50,100,150$, and $200 \mathrm{ppm})$ for 15, 30, 45, and $60 \mathrm{~min}$. The most effective condition to eliminate E. coli and Salmonella spp. from alfalfa seeds was sequential immersion in water for $5 \mathrm{~h}$ and $200 \mathrm{ppm} \mathrm{ClO}_{2}$ treatment for $1 \mathrm{~h}$. After the optimal condition was applied to eight kinds of sprout seeds, the pathogens were completely inactivated in all seeds, except radish seeds. Growth of pathogenic $E$. coli and Salmonella spp. during sprouting after $\mathrm{ClO}_{2}$ treatment of alfalfa seeds was also completely inactivated. However, the germination rate of seeds did not significantly decrease after $\mathrm{ClO}_{2}$ treatment. In addition, $\mathrm{ClO}_{2}$ residues were not present in any sprout during 3 days of cultivation. These results demonstrated that sequential presoaking and $200 \mathrm{ppm} \mathrm{ClO}_{2}$ treatment is the optimal seed disinfection treatment to prevent foodborne diseases associated with sprout consumption.
\end{abstract}

Keywords: Chlorine dioxide, Pre-soaking, Pathogenic Escherichia coli, Salmonella spp., Sprout seed

\section{Introduction}

Sprouted seed is gaining popularity globally due to its health-promoting biocapacity, including the prevention of arteriosclerosis, alleviation of osteoporosis, and reduced risk of cardiovascular diseases $[1,2]$. However, seed and sprout also have been recognized as a possible causative vehicle involved in a number of

\footnotetext{
*Correspondence: seri81@korea.kr

${ }_{1}^{1}$ Microbial Safety Team, Department of Agro-Food Safety \& Crop Protection, National Institute of Agricultural Sciences (NAS), Rural Development Administration (RDA), Wanju 55365, Republic of Korea Full list of author information is available at the end of the article
}

foodborne diseases and illnesses. In particular, alfalfa, mung bean, radish, and clover seeds or sprouts were reported as an important reservoir causing multi-state oubtreaks of Escherichia coli O157:H7 and various Salmonella serotype infections in Canada, Japan, United Kingdom, and the United States [3-5]. Sprouted seeds were demonstrated to be linked with at least 33 outbreaks between 1998 and 2010 in the United States, concomitantly with 1330 suspected patients [6]. Consumption of radish sprouts contaminated with Shiga toxin producing Escherichia coli O104:H4 (STEC) accounted for approximately 4 haemolytic uraemic syndromes (HUS) and 3 STEC cases in Germany, 
2011 [7]. An epidemiological and molecular genotyping study showed that a total of 45 cases of Salmonella Weltevreden infection originated from alfalfa sprouts in Sweden, Finland, and Denmark [8].

The optimal temperature and high amounts of moisture under sprouting or germination conditions may contribute to the rapid growth of either resident microflora or pathogenic bacteria [9]. Then, soaking seed sprouts in 20,000 ppm calcium hypochlorite prior to their cultivation is recommended by U.S. Food and Drug Administration [3]. However, previous studies have demonstrated that chlorine-based sanitizers are ineffective for removing or eliminating $E$. coli O157:H7 and Salmonella spp. inoculated on seed sprouts [10-12]. In a study conducted by Taormina et al. [9], the efficacy of chlorine-based sanitizers on the decontamination of E. coli O157:H7 and Salmonella spp. in seeds or sprouts is well-documented, and the authors highlighted that chlorine, $\mathrm{NaOCl}$ and $\mathrm{Ca}(\mathrm{OCl})_{2}$ at $100-2000 \mathrm{ppm}$ resulted in less than $10^{1-3}$ $\mathrm{CFU} / \mathrm{g}$ reductions. In order to overcome this limitation, heating [1], packaging [13], ozone [14], organic acid [10[, ozonated water [15], electrolyzed oxidizing water [16], and ultraviolet irradiation [17] have been applied to develop an effective alternative for inactivating pathogenic bacteria on seed or sprout products. Nevertheless, the localization of pathogens in some cracks, scars or damaged areas on the surface can contribute to the decreased effectiveness of these sanitizing methods [18]. The potential internalization of $E$. coli O157:H7 and Salmonella spp. into the inferior tissue may minimize the contact with the organisms and sanitizers. Moreover, sequential presoaking in water and hydrostatic pressure (HHP; $600 \mathrm{MPa}$ ) reduced the number of E. coli $\mathrm{O} 157: \mathrm{H} 7$ and Salmonella spp. in seeds below the detection limits, but the germination potential of seeds also was decreased substantially [19]. Hence, there is an urgent need to develop an effective decontamination strategy, which does not affect the seed-viability. Chlorine dioxide is a derivative chlorine compound, thus it has not only inherits the properties of chlorine but also got the superior properties such as 10 time more soluble in water then chlorine, no taste and odour [20]. It can be use as an alternative disinfectant to chlorine. Therefore, the purpose of the present study was to evaluate the effect of presoaking seeds in water on the inactivation of pathogenic E. coli and Salmonella spp. on sprout seeds using $\mathrm{ClO}_{2}$. The optimal conditions for sequential presoaking and $\mathrm{ClO}_{2}$ treatment to E. coli and Salmonella spp. without substantially reducing the viability of seeds were established.

\section{Materials and methods}

\section{Preparation of inocula and inoculation of seeds}

Preliminarily, three strains of $E$. coli were isolated from irrigation water, kohlrabi, and radish sprouts harvested in Republic of Korea, 2018 and demonstrated to harbor eaeA, ipaH, and stx 2 via PCR assays. Three kinds of Salmonella Typhimurium strains (ATCC 4931, ATCC 19585, and NCCP 13697) were used in this study. Planting the inocula on a medium containing rifampicin allowed the suppression of growth of seed commensals; thus, rifampicin resistance was induced in all those strains. To obtain spontaneous rifampicin resistance, all strains were cultured in Luria-Bertani broth (BD Difco ${ }^{\mathrm{TM}}$, Sparks, MD, USA) supplemented with $50 \mu \mathrm{g} \mathrm{mL} \mathrm{m}^{-1}$ rifampicin (Biosesang, Seongnam, Gyeonggi-do, South Korea) at $37{ }^{\circ} \mathrm{C}$ for $18 \mathrm{~h}$ at $180 \mathrm{rpm}$. Each strain was then streaked on tryptic soy agar (TSA; Oxoid, Basingstoke, UK) supplemented with $50 \mu \mathrm{g} \mathrm{mL}^{-1}$ rifampicin (TSA-R) and incubated at $37{ }^{\circ} \mathrm{C}$ for $24 \mathrm{~h}$ followed by subculturing under identical conditions to isolate rifampicin-resistant strains. Colonies were then inoculated into $7 \mathrm{~mL}$ tryptic soy broth (TSB; Oxoid, Basingstoke, UK) supplemented with $50 \mu \mathrm{g} \mathrm{mL}{ }^{-1}$ rifampicin (TSB-R) and enriched at $37{ }^{\circ} \mathrm{C}$ for $16 \mathrm{~h}$ at $180 \mathrm{rpm}$. Each enriched culture was centrifuged at $4000 \mathrm{rpm}$ at $4{ }^{\circ} \mathrm{C}$ for $15 \mathrm{~min}$. Cells were washed twice with $10 \mathrm{~mL}$ phosphate-buffered saline (PBS; Oxoid) and resuspended in $10 \mathrm{~mL}$ PBS. Each culture cocktail of pathogenic E. coli and Salmonella spp. was checked and adjusted at O.D. 600 by 1 $\left(\sim 10^{9} \mathrm{CFU} \mathrm{mL} \mathrm{mL}^{-1}\right)$. Then, these cell suspensions were serially diluted at $1: 10$ until they reach $10^{5} \mathrm{CFU} \mathrm{mL}^{-1}$ with PBS.

Nine different kinds of sprout seeds (Dongwoobio Co., Ltd., Gyeonggi-do, South Korea), including alfalfa (Medicago sativa), radish (Radishes raphanistrum subsp. sativus), red kohlrabi (Brassica oleracea), tatsoi (Brassica rapa), kohlrabi (B. oleracea), crimson clover (Trifolium incarnatum L.), cabbage (B. oleracea), red radish ( $R$. raphanistrum subsp. sativus), and rapeseed (Brassica napus L.), were used in this study. All seeds used in the study were purchased from an agricultural material market in Jeollabuk-do, Republic of Korea and stored at $4{ }^{\circ} \mathrm{C}$. The seeds were previously screened to ensure that no presumptive E. coli or Salmonella-like colonies were recovered from uninoculated samples. Each seed sample $(450 \mathrm{~g})$ was placed in $450 \mathrm{~mL}$ of each mixed cell suspension and gently agitated for $10 \mathrm{~min}$. The cell suspension was drained and the seeds were placed on an aluminum foil and dried in a laminar flow hood at $22 \pm 1{ }^{\circ} \mathrm{C}$ for $18 \mathrm{~h}$ before use in downstream experiments. 


\section{Preparation of $\mathrm{ClO}_{2}$ solution}

The $\mathrm{ClO}_{2}$ solution was prepared immediately before use. Aqueous $\mathrm{ClO}_{2}(50,100,150$, and $200 \mathrm{ppm})$ was prepared by adding $1,2,3$, and $4 \mathrm{~g} \mathrm{ClO}_{2}$ (Vibrex; Agranco, South Korea) in $1 \mathrm{~L}$ distilled water, respectively. In addition, $\mathrm{NaOCl}$ (Yuhan Co., Ltd., Gyeonggido, South Korea) was used as control in this study. $\mathrm{NaOCl}(200 \mathrm{ppm})$ was prepared by diluting $1.6 \mathrm{~mL}$ of $12.5 \% \mathrm{NaOCl}$ to $1 \mathrm{~L}$ sterile distilled water. The concentration of free chlorine in $\mathrm{NaOCl}$ and $\mathrm{ClO}_{2}$ solutions was determined using quick chlorine test kits (highrange chlorine dioxide; La Motte, USA) and chlorine detector (1200 colorimeter; La Motte), respectively.

\section{Evaluate the synergic effect of presoaking on the inactivation of pathogenic E. coli and Salmonella spp. on alfalfa seeds using $\mathrm{ClO}_{2}$}

To determine the synergic effect of presoaking on the inactivation of pathogenic E. coli and Salmonella spp. on alfalfa seeds using $\mathrm{ClO}_{2}, \mathrm{ClO}_{2}$ was applied to unsoaked and presoaked seeds. Briefly, $10 \mathrm{~g}$ of each seed sample inoculated with pathogenic E. coli and Salmonella spp. were placed in $50 \mathrm{~mL}$ sterile plastic tube. Before $\mathrm{ClO}_{2}$ treatment, seeds were immersed in $40 \mathrm{~mL}$ distilled water at room temperature for $5 \mathrm{~h}$ for soaking treatment, and then distilled water was drained. Then, $40 \mathrm{~mL}$ of $200 \mathrm{ppm}$ $\mathrm{NaOCl}$ and four different concentrations of $\mathrm{ClO}_{2}$ (50, 100,150 , and $200 \mathrm{ppm}$ ) were dispensed into a $50 \mathrm{~mL}$ plastic tube of the above samples, respectively. Each sample was treated for $15 \mathrm{~min}$ and the sanitizer was drained. Each treated seed was placed into a sterile plastic bag with $90 \mathrm{~mL}$ DE neutralizing broth (BD Difco ${ }^{\mathrm{TM}}$, Sparks, $\mathrm{MD}$, USA) to neutralize the effect of the disinfectant. Bacteria were detached using a stomacher (Bagmixer 400VW; Interscience ${ }^{\circledR}$, Paris, France) for $1 \mathrm{~min}$ at speed 7. Homogenates $(1 \mathrm{~mL})$ were serially diluted in $9 \mathrm{~mL}$ of $0.1 \%$ peptone water, and $0.2 \mathrm{~mL}$ of each dilution was spread on TSA-R. Plates were incubated at $37^{\circ} \mathrm{C}$ for $24 \mathrm{~h}$, and the colonies were counted manually.

\section{Optimization of $\mathrm{ClO}_{2}$ treatment condition in presoaked alfalfa seeds}

To determine the most optimal concentration and treatment time to reduce pathogenic E. coli and Salmonella spp. in alfalfa seeds, inoculated seeds were exposed to four different concentrations of $\mathrm{ClO}_{2}(50,100,150$, and $200 \mathrm{ppm}$ ) for $15,30,45$, and $60 \mathrm{~min}$. Briefly, $10 \mathrm{~g}$ of the inoculated seeds were immersed in $40 \mathrm{~mL}$ distilled water for $5 \mathrm{~h}$, followed by draining the water before $\mathrm{ClO}_{2}$ treatment. Then, $40 \mathrm{~mL}$ of the four different concentrations of $\mathrm{ClO}_{2}$ were added into $5 \mathrm{~h}$ presoaked seeds inoculated with pathogenic E. coli or Salmonella spp. individually.
After each sample was treated for 15, 30, 45, and $60 \mathrm{~min}$, the sanitizer was drained. Each treated seed unit was placed into a sterile plastic bag with $90 \mathrm{~mL}$ DE neutralizing broth (BD Difco ${ }^{\mathrm{TM}}$ ) to neutralize the effect of the disinfectant. Bacterial analysis was performed using the aforementioned method.

\section{Growth of pathogenic E. coli and Salmonella spp. during sprouting after $\mathrm{ClO}_{2}$ treatment of presoaked seeds} To estimate the microbiological risks of sprouts produced from alfalfa seeds treated with $\mathrm{ClO}_{2}$, populations of pathogenic E. coli and Salmonella spp. in sprouts during cultivation were determined. The treatment steps have done follow above method, and the each treated seed was placed on a dish covered with Whatman paper No. 2 (Advantec Toyo Kaisha, Tokyo, Japan), 4 mL sterile distilled water was added, and sterile distilled water was then periodically provided to maintain the amount of moisture required for sprouting. Seeds were incubated at $25^{\circ} \mathrm{C}$ for 3 days. Each sample was withdrawn at 3, 6, 9, $18,24,48$, and $72 \mathrm{~h}$. And bacterial population were also done using the aforementioned method.

For evaluation the present or absence of those pathogenes. the selective agar medium were used. Briefly, for pathogenic E. coli, after enrichment step in EC broth, the enriched sample was streaked onto an eosin methylene blue (EMB) agar (Oxoid) plate using a sterile disposable loop and incubated at $37^{\circ} \mathrm{C}$ for $24 \mathrm{~h}$. The typical morphology of $E$. coli developed green metal color on EMB plate. For the detection of Salmonella spp., after enrichment step in buffe peptone water (Oxoid), the enriched sample $(0.1 \mathrm{~mL})$ was inoculated into $10 \mathrm{~mL}$ RappaportVassiliadis (Oxoid) enrichment broth before incubation at $42{ }^{\circ} \mathrm{C}$ for $24 \mathrm{~h}$. A loopful of each enrichment culture was then streaked onto XLT-4 (Oxoid) agar. After incubation at $37{ }^{\circ} \mathrm{C}$ for $24 \mathrm{~h}$, black colonies were picked for confirmation. Suspected colonies of E. coli and Salmonella spp. were identified by VITEK, which automatically identifies foodborne pathogens on a biochemical basis.

\section{Application of optimal $\mathrm{ClO}_{2}$ treatment conditions to various seeds}

To verify whether the $\mathrm{ClO}_{2}$ treatment condition optimized in alfalfa seeds is applicable to other sprout seeds, the performance of optimized condition was assessed using eight kinds of sprout seeds, including radish, red kohlrabi, tatsoi, kohlrabi, crimson clover, cabbage, red radish, and rapeseed. Eight kinds of seeds were inoculated with pathogenic E. coli and Salmonella spp. at initial levels of 2.0 and $4.0 \log \mathrm{CFU} \mathrm{g}^{-1}$ using the aforementioned method. The optimal method of $5 \mathrm{~h}$ presoaking and major treatment (200 ppm $\mathrm{ClO}_{2}$ for $60 \mathrm{~min}$ ) was also applied to treat all kinds of seeds. Then, each set of 

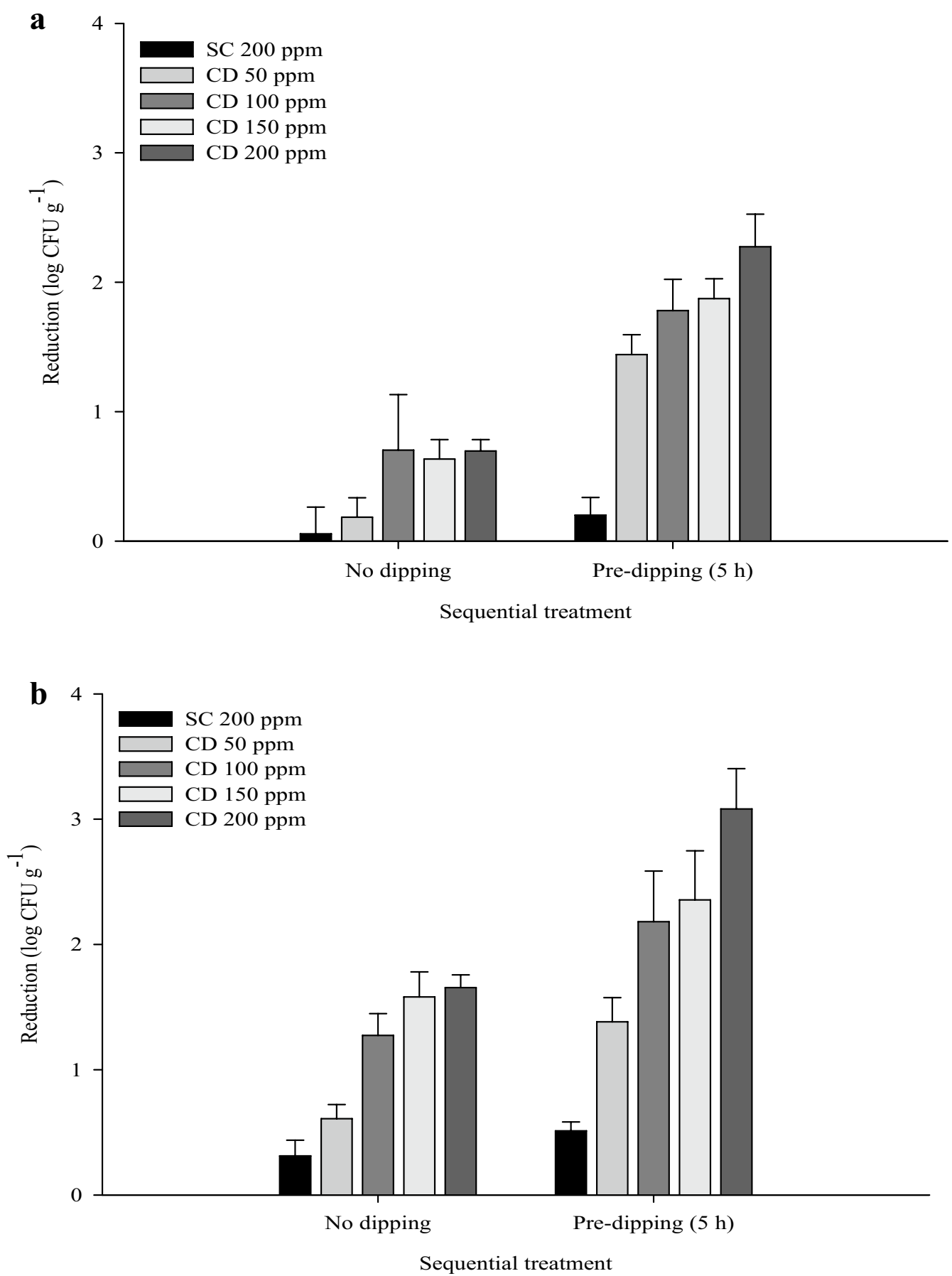

Fig. 1 Comparison between non-soaking and pre-soaking to the effect of $\mathrm{ClO}_{2}$ treatment on the inactivation of pathogenic $E$. coli (a) and Salmonella spp. (b) in alfalfa seeds

seed was scattered on a plate with Whatman paper No. 2, $5 \mathrm{~mL}$ sterile distilled water was added, and sterile distilled water was periodically provided to maintain the amount of moisture required for sprouting. After cultivation for 3 days, each set of sprout was analyzed to determine the presence of pathogenic E. coli and Salmonella spp. in sprouts by the aforementioned method. Various sprout seeds treated with $\mathrm{ClO}_{2}$ before cultivation were also analyzed for pathogenic E. coli and Salmonella spp. 


\section{Determination of seed germination rate}

To investigate the effect of $\mathrm{ClO}_{2}$ treatment on seed germination, treated or untreated seeds after soaking $(n=100)$ were placed on two plates of Petridish $(90 \mathrm{~mm}$ in diameter) covered with Whatman paper No. 2. 4 to $6 \mathrm{~mL}$ of distilled water was added to each Petri dish, and distilled water was periodically provided to maintain the moisture content required for sprouting. The seeds were incubated at $25^{\circ} \mathrm{C}$ for 3 days. Only seeds with a protruding hypocotyl were counted as a sprout every day, and ruptured or swollen seeds were not counted. The germination rate was determined as the proportion of sprout seeds to the total number of seeds. Experiments were performed in triplicate.

\section{Determination of residue of $\mathrm{ClO}_{2}$}

The concentration of residual $\mathrm{ClO}_{2}$ in seeds after sterilization was performed by iodometric analysis. Briefly, pulverized seeds were quickly placed into $50 \mathrm{~mL}$ polyethylene tubes containing $20 \mathrm{~mL}$ phosphate buffer followed by $2 \mathrm{~g} \mathrm{KI}$. After shaking, the sample was allowed to stand for 10 min under dark conditions, and the solution was titrated with $0.1 \mathrm{~N} \mathrm{Na}_{2} \mathrm{~S}_{2} \mathrm{O}_{3}$.
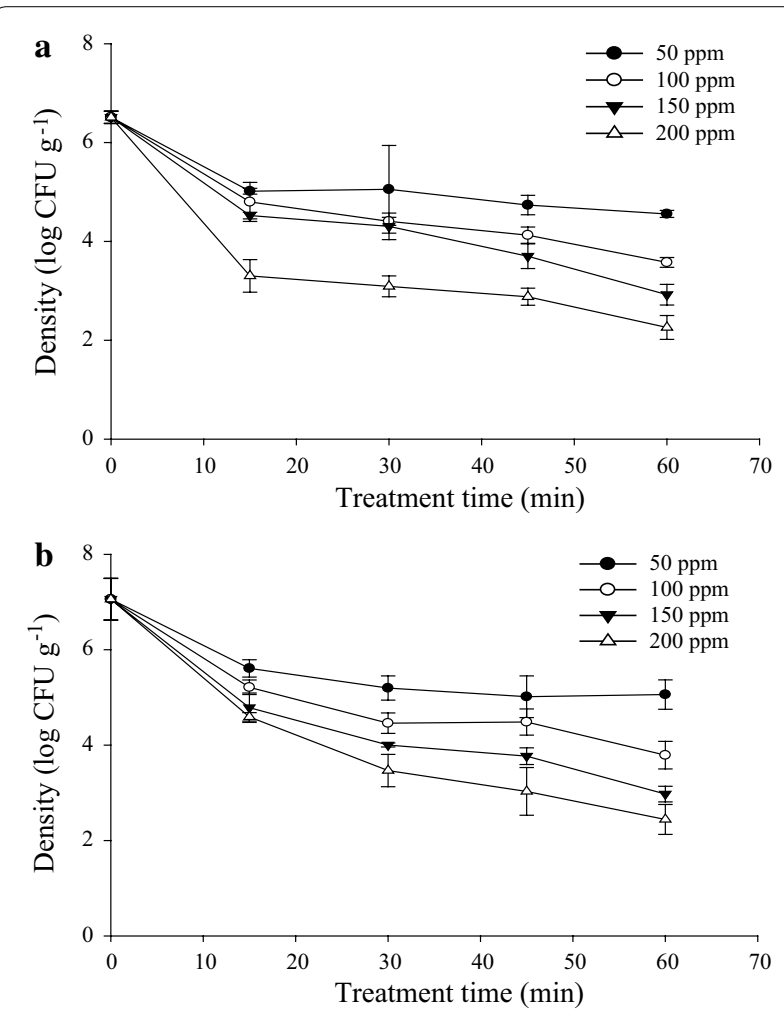

Fig. 2 Effect of sequential presoaking and $\mathrm{ClO}_{2}$ treatment on inactivation of pathogenic E. coli (a) and Salmonella spp. (b)

\section{Statistical analysis}

This study was repeated twice with triplicate samples per replication. For statistical analysis, microbiological data were transformed to $\log \mathrm{CFU} \mathrm{g}{ }^{-1}$ and analyzed using SAS software (SAS Institute, Inc., USA). All comparisons of means were performed using Tukey's multiple range test at alpha $=0.05$.

\section{Results}

Evaluate the synergic effect of presoaking

on the inactivation of pathogenic E. coli and Salmonella spp. on alfalfa seeds using $\mathrm{ClO}_{2}$

Figure 1 shows the reduced populations of pathogenic E. coli and Salmonella spp. in unsoaked and presoaked alfalfa seeds after $\mathrm{ClO}_{2}$ treatment. There were significant differences $(p<0.05)$ in the reduced number of bacteria among types of condition of seeds, pathogens, and sanitizers. After $\mathrm{ClO}_{2}$ treatment, the reduced pathogen numbers in presoaked seeds were higher than those in unsoaked seeds. Furthermore, the reduced number of pathogenic E. coli was lower $(p<0.05)$ than those of Salmonella spp. However, there were no
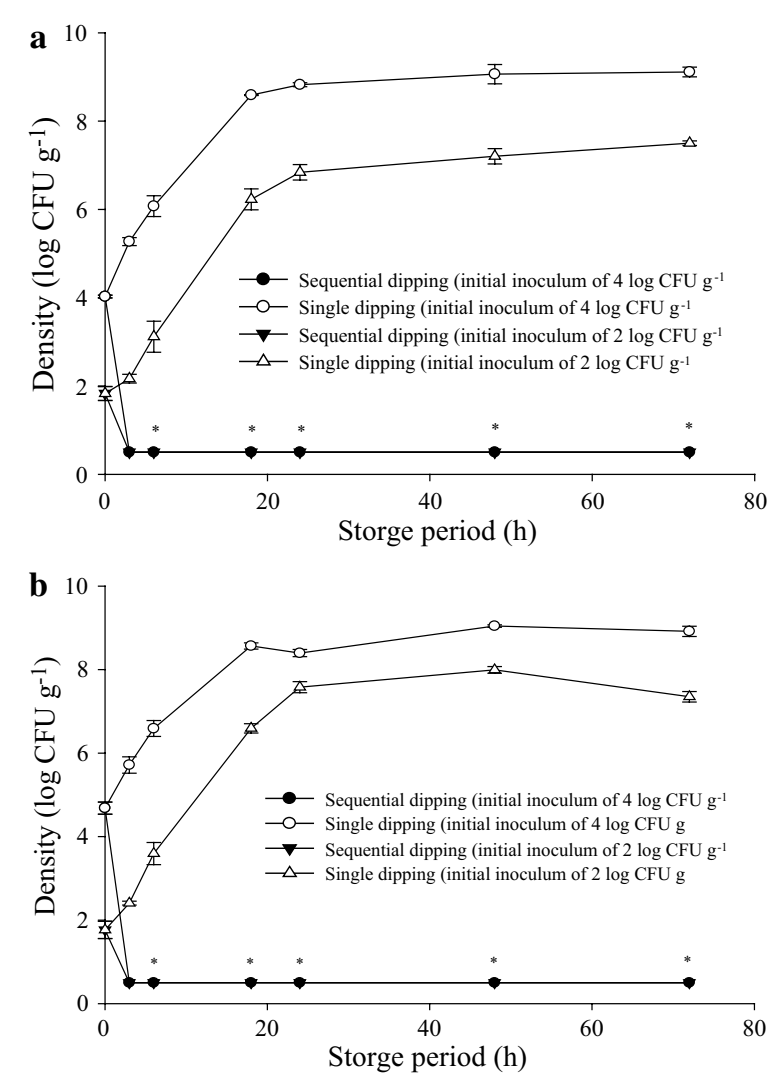

Fig. 3 Growth of pathogenic E. coli (a) and Salmonella spp. (b) during sprouting after sequential presoaking and $\mathrm{ClO}_{2}$ treatment in alfalfa seeds 
significant reductions $(p>0.05)$ in pathogen numbers in seeds treated with $200 \mathrm{ppm} \mathrm{NaOCl}$ used as control. As the concentration of $\mathrm{ClO}_{2}$ increased from 50 to $200 \mathrm{ppm}$ in presoaked seeds, the pathogen numbers decreased further. When alfalfa seeds were exposed to 50, 100, 150, and $200 \mathrm{ppm} \mathrm{ClO}_{2}$ for $15 \mathrm{~min}$, the numbers of pathogenic $E$. coli in presoaked seeds were reduced more $(p<0.05)$ than those in unsoaked seeds by $1.25,1.07,1.63$, and $2.07 \log \mathrm{CFU} \mathrm{g} \mathrm{g}^{-1}$, respectively. Sequential presoaking and 50,100,150, and $200 \mathrm{ppm}$ $\mathrm{ClO}_{2}$ for 15 min caused 1.38, 2.18, 2.35, and $3.08 \mathrm{log}$ CFU g ${ }^{-1}$ reductions of Salmonella spp., respectively. However, $\mathrm{ClO}_{2}$ treatment alone was less effective at reducing the population of Salmonella spp. in alfalfa seeds compared to sequential presoaking and $\mathrm{ClO}_{2}$ treatment, with $0.61,1.27,1.58$, and $1.65 \log$ CFU g ${ }^{-1}$ reductions of Salmonella spp., respectively. Our results indicated that presoaking and then $\mathrm{ClO}_{2}$ treatment have a synergic effect in reducing foodborne pathogens in alfalfa seeds compared to unsoaked.

\section{Optimization of $\mathrm{ClO}_{2}$ treatment in presoaked alfalfa seeds}

The inactivation of the numbers of pathogenic E. coli and Salmonella spp. in alfalfa seeds was significantly affected by concentration and treatment time. $\mathrm{As}^{\mathrm{ClO}_{2}}$ concentration and treatment time increased, the numbers of pathogenic E. coli and Salmonella spp. were decreased. Aqueous $\mathrm{ClO}_{2}$ (50, 100, 150, and $\left.200 \mathrm{ppm}\right)$ treatment for $1 \mathrm{~h}$ after soaking seeds for $5 \mathrm{~h}$ caused $1.95,3.00,2.93$, and $4.00 \log \mathrm{CFU} \mathrm{g} \mathrm{g}^{-1}$ reductions

Table 1 Presence of pathogenic $E$. coli and Salmonella spp. on various seeds and sprouts after application of the optimized $\mathrm{ClO}_{2}$ treatment condition

\begin{tabular}{|c|c|c|c|c|c|c|c|c|}
\hline \multirow[t]{3}{*}{ Seeds } & \multicolumn{8}{|c|}{ Initial level on the seed } \\
\hline & \multicolumn{2}{|c|}{ Present of $E$. coli on seed } & \multicolumn{2}{|c|}{ Present of $E$. coli on sprout } & \multicolumn{2}{|c|}{$\begin{array}{l}\text { Present of Salmonella spp. } \\
\text { on seed }\end{array}$} & \multicolumn{2}{|c|}{$\begin{array}{l}\text { Present of Salmonella } \\
\text { on sprout }\end{array}$} \\
\hline & $2 \log \mathrm{CFU} \mathrm{g}^{-1}$ & $4 \log \mathrm{CFU} \mathrm{g}^{-1}$ & $2 \log \mathrm{CFU} \mathrm{g}^{-1}$ & $4 \log \mathrm{CFU} \mathrm{g}^{-1}$ & $2 \log \mathrm{CFU} \mathrm{g}^{-1}$ & $4 \log C F U g^{-1}$ & $2 \log \mathrm{CFU} \mathrm{g}{ }^{-1}$ & $4 \log \mathrm{CFU} \mathrm{g}^{-1}$ \\
\hline Radish & $3 / 3^{*}$ & $3 / 3$ & $3 / 3$ & $3 / 3$ & $3 / 3$ & $3 / 3$ & $3 / 3$ & $3 / 3$ \\
\hline Red radish & $0 / 3$ & $0 / 3$ & $0 / 3$ & $0 / 3$ & $0 / 3$ & $0 / 3$ & $0 / 3$ & $0 / 3$ \\
\hline Crimson clover & $0 / 3$ & $0 / 3$ & $0 / 3$ & $0 / 3$ & $0 / 3$ & $0 / 3$ & $0 / 3$ & $0 / 3$ \\
\hline Kohlrabi & $0 / 3$ & $0 / 3$ & $0 / 3$ & $0 / 3$ & $0 / 3$ & $0 / 3$ & $0 / 3$ & $0 / 3$ \\
\hline Red Kohlrabi & $0 / 3$ & $0 / 3$ & $0 / 3$ & $0 / 3$ & $0 / 3$ & $0 / 3$ & $0 / 3$ & $0 / 3$ \\
\hline Rape seed & $0 / 3$ & $0 / 3$ & $0 / 3$ & $0 / 3$ & $0 / 3$ & $0 / 3$ & $0 / 3$ & $0 / 3$ \\
\hline Tatsoi & $0 / 3$ & $0 / 3$ & $0 / 3$ & $0 / 3$ & $0 / 3$ & $0 / 3$ & $0 / 3$ & $0 / 3$ \\
\hline Cabbage & $0 / 3$ & $0 / 3$ & $0 / 3$ & $0 / 3$ & $0 / 3$ & $0 / 3$ & $0 / 3$ & $0 / 3$ \\
\hline
\end{tabular}

* Present of E. coli or Salmonella spp. on seed or sprout = the number of positive samples/the number of tested samples

Table 2 Germination rate of various seeds after sequential presoaking and $\mathrm{ClO}_{2}$ treatment

\begin{tabular}{|c|c|c|c|c|c|c|}
\hline \multirow[t]{3}{*}{ Seeds } & \multicolumn{6}{|c|}{ Germination rate (\%) } \\
\hline & \multicolumn{2}{|l|}{1 day } & \multicolumn{2}{|l|}{2 days } & \multicolumn{2}{|l|}{3 days } \\
\hline & Untreated & $\mathrm{ClO}_{2}$ treated & Untreated & $\mathrm{ClO}_{2}$ treated & Untreated & $\mathrm{ClO}_{2}$ treated \\
\hline Radish & $87.7^{\mathrm{a}}$ & $85.3^{\mathrm{a}}$ & $94.0^{\mathrm{a}}$ & $93.7^{\mathrm{a}}$ & $97.0^{\mathrm{a}}$ & $97.0^{\mathrm{a}}$ \\
\hline Red Radish & $88.0^{\mathrm{a}}$ & $86.3^{\mathrm{a}}$ & $94.0^{\mathrm{a}}$ & $93.3^{\mathrm{a}}$ & $96.7^{\mathrm{a}}$ & $97.7^{\mathrm{a}}$ \\
\hline Crimson clover & $73.7^{\mathrm{a}}$ & $57.7^{b}$ & $82.7^{\mathrm{a}}$ & $85.0^{\mathrm{a}}$ & $84.0^{\mathrm{a}}$ & $87.7^{\mathrm{a}}$ \\
\hline Kohlrabi & $71.7^{\mathrm{a}}$ & $80.7^{\mathrm{a}}$ & $96.3^{\mathrm{a}}$ & $92.0^{\mathrm{a}}$ & $98.0^{\mathrm{a}}$ & $96.3^{\mathrm{a}}$ \\
\hline Red Kohlrabi & $85.3^{\mathrm{a}}$ & $87.7^{\mathrm{a}}$ & $96.0^{\mathrm{a}}$ & $93.0^{\mathrm{a}}$ & $97.0^{\mathrm{a}}$ & $93.7^{\mathrm{a}}$ \\
\hline Rape seed & $76.0^{\mathrm{a}}$ & $78.0^{\mathrm{a}}$ & $90.7^{\mathrm{a}}$ & $87.7^{\mathrm{a}}$ & $94.0^{\mathrm{a}}$ & $91.7^{\mathrm{a}}$ \\
\hline Tatsoi & $50.3^{b}$ & $88.0^{\mathrm{a}}$ & $97.7^{\mathrm{a}}$ & $96.0^{\mathrm{a}}$ & $99.0^{\mathrm{a}}$ & $98.3^{\mathrm{a}}$ \\
\hline Cabbage & $76.0^{\mathrm{a}}$ & $79.0^{\mathrm{a}}$ & $90.7^{\mathrm{a}}$ & $84.7^{\mathrm{a}}$ & $92.0^{\mathrm{a}}$ & $93.0^{\mathrm{a}}$ \\
\hline Alfalfa & $87.0^{b}$ & $95.0^{\mathrm{a}}$ & $93.0^{\mathrm{b}}$ & $97.0^{\mathrm{a}}$ & $97.0^{\mathrm{a}}$ & $98.0^{\mathrm{a}}$ \\
\hline
\end{tabular}

The same letters in each row are not significantly different from the germination rate in the comparison between untreated and $\mathrm{ClO}_{2}$-treated groups on the same day with $\mathrm{p}<0.05$ according to Tukey's test 
of pathogenic E. coli in alfalfa seeds, respectively $(p<0.05)$. When presoaked alfalfa seeds were exposed to $200 \mathrm{ppm} \mathrm{ClO}_{2}$ for $15,30,45$, and $60 \mathrm{~min}$, the population of pathogenic $E$. coli was significantly decreased by $2.20,3.00,3.40$, and $4.00 \log C F U ~ g^{-1}$ compared to untreated samples, respectively $(p<0.05)$. The inactivation of Salmonella spp. in alfalfa seeds after $\mathrm{ClO}_{2}$ treatment showed a similar pattern as those of pathogenic E. coli. The number of Salmonella spp. in alfalfa seeds was reduced by $2.00,3.27,4.09$, and $4.26 \log \mathrm{CFU} \mathrm{g}^{-1}$ after treatment with $50,100,150$, and $200 \mathrm{ppm} \mathrm{ClO}_{2}$ for $1 \mathrm{~h}$. At the level of $200 \mathrm{ppm}$, Salmonella spp. in alfalfa seeds exposed for $1 \mathrm{~h}$ were inactivated faster compared to those exposed to $30 \mathrm{~min}$. These results demonstrated that sequential immersion in water for $5 \mathrm{~h}$ and $200 \mathrm{ppm}$ $\mathrm{ClO}_{2}$ treatment for $1 \mathrm{~h}$ was the optimal condition to eliminate E. coli and Salmonella spp. from alfalfa seeds (Fig. 2).

\section{Growth of pathogenic E. coli and Salmonella spp. during sprouting after $\mathrm{ClO}_{2}$ treatment of alfalfa seeds}

Figure 3 shows the growth of pathogenic E. coli and Salmonella spp. during sprouting after treatment of presoaked alfalfa seeds. Pathogenic E. coli and Salmonella spp. were completely inactivated in presoaked alfalfa seeds after treatment of $200 \mathrm{ppm} \mathrm{ClO}_{2}$ for $1 \mathrm{~h}$, regardless of the inoculation level of pathogens. When these pathogens were completely inactivated in alfalfa seeds, the pathogens were not detected after sprouting. However, when seeds contaminated with pathogenic $E$. coli at 2.0 and $4.0 \log \mathrm{CFU} \mathrm{g}{ }^{-1}$ were not treated with $\mathrm{ClO}_{2}$, subsequent sprouting resulted in populations of $E$. coli at 6.0 and $8.0 \log \mathrm{CFU} \mathrm{g}{ }^{-1}$, respectively. Salmonella spp. in alfalfa seeds were also increased to $7-8 \log$ CFU g ${ }^{-1}$ after 3 days of sprouting. These results emphasized the importance of the elimination of foodborne pathogens on sprout seeds to prevent foodborne diseases associated with sprout consumption. In addition, $200 \mathrm{ppm} \mathrm{ClO}_{2}$ treatment for $1 \mathrm{~h}$ after presoaking for $5 \mathrm{~h}$ can enhance the safety of alfalfa sprouts.

\section{Application of optimized $\mathrm{ClO}_{2}$ treatment condition to various seeds}

Table 1 shows the results of the application of optimized $\mathrm{ClO}_{2}$ treatment conditions to eight kinds of seeds. Pathogenic E. coli and Salmonella spp. were not detected in all kinds of seeds, except radish seeds, treated with $200 \mathrm{ppm}$ $\mathrm{ClO}_{2}$ for $1 \mathrm{~h}$ after soaking for $5 \mathrm{~h}$. After sprouting for 3 days, these pathogens were not also detected from each sprout when each seed was treated with optimized $\mathrm{ClO}_{2}$ treatment condition. However, the optimized $\mathrm{ClO}_{2}$ treatment condition for alfalfa seeds does not have an effect on the inactivation of pathogenic E. coli and Salmonella spp. on radish seeds. Thus, pathogenic E. coli and Salmonella spp. were detected after sprouting for 3 days. These results indicated that the optimal condition for alfalfa seeds was also applicable for the inactivation of pathogenic E. coli and Salmonella spp. in various seeds, except radish seeds.

\section{Determination of seed germination rate}

Seed viability was evaluated by monitoring the germination percentage during 3 days. The germination rates of nine kinds of untreated and treated seeds are shown in Table 2. The mean germination rates of nine kinds of seeds on the third day of germination ranged from $84 \%$ to $98 \%$.

Overall, the germination rates of nine kinds of sprout seeds with $200 \mathrm{ppm} \mathrm{ClO}_{2}$ for $1 \mathrm{~h}$ after soaking for $5 \mathrm{~h}$

Table 3 Residue of $\mathrm{ClO}_{2}$ on various seeds after sequential presoaking and $\mathrm{ClO}_{2}$ treatment

\begin{tabular}{|c|c|c|c|c|c|c|c|c|c|}
\hline \multirow[t]{2}{*}{ Seed name } & \multicolumn{9}{|c|}{ The residual of $\mathrm{ClO}_{2}$ in the seed after treatment $(\mathrm{h})$} \\
\hline & 0 & 1 & 2 & 4 & 8 & 12 & 24 & 48 & 72 \\
\hline Red radish & N.D & N.Da & N.Da & N.Da & N.Da & N.D ${ }^{a}$ & N.D ${ }^{a}$ & N.D ${ }^{a}$ & N.D $\mathrm{D}^{\mathrm{a}}$ \\
\hline Crimson clover & $23.1 \pm 4.4^{\mathrm{a}}$ & N.D & N.D $D^{b}$ & N.D b & N.D & N.D & N.D ${ }^{b}$ & N.D ${ }^{b}$ & $N . D^{b}$ \\
\hline Red Kohlrabi & $20.0 \pm 4.0^{a}$ & $N . D^{b}$ & $N . D^{b}$ & $N . D^{b}$ & $N . D^{b}$ & N.D ${ }^{b}$ & N.D ${ }^{b}$ & N.D ${ }^{b}$ & $N \cdot D^{b}$ \\
\hline Radish & $59.4 \pm 11.5^{a}$ & $30.3 \pm 9.7^{b}$ & $9.7 \pm 3.5^{c}$ & N.D ${ }^{d}$ & N.D ${ }^{d}$ & N.D ${ }^{d}$ & N.D ${ }^{d}$ & N.D ${ }^{d}$ & N.D ${ }^{d}$ \\
\hline Tatsoi & $71.5 \pm 7.2^{\mathrm{a}}$ & $42.4 \pm 3.1^{b}$ & $24.5 \pm 1.9^{c}$ & N.D ${ }^{d}$ & N.D ${ }^{d}$ & N.D ${ }^{d}$ & N.D ${ }^{d}$ & N.D ${ }^{d}$ & N.D ${ }^{d}$ \\
\hline Kohlrabi & $110.8 \pm 18.0^{a}$ & $88.8 \pm 16.9^{a}$ & $57.1 \pm 13.1^{b}$ & $35.0 \pm 7.9^{c}$ & $N . D^{d}$ & N.D ${ }^{d}$ & N.D ${ }^{d}$ & N.D ${ }^{d}$ & N.D ${ }^{d}$ \\
\hline Rape seed & $112.2 \pm 17.4^{\mathrm{a}}$ & $74.3 \pm 18.5^{b}$ & $50.6 \pm 14.4^{b}$ & $21.3 \pm 7.7^{c}$ & N.D ${ }^{d}$ & N.D ${ }^{d}$ & N.D ${ }^{d}$ & N.D ${ }^{d}$ & N.D ${ }^{d}$ \\
\hline Cabbage & $111.7 \pm 13.9^{a}$ & $92.8 \pm 14.7^{\mathrm{a}}$ & $67.8 \pm 15.6^{b}$ & $10.2 \pm 0.6^{c}$ & N.D ${ }^{d}$ & $N . D^{d}$ & N.D ${ }^{d}$ & N.D ${ }^{d}$ & N.D ${ }^{d}$ \\
\hline Alfalfa & $196.1 \pm 24.5^{a}$ & $151.8 \pm 10.9^{b}$ & $115.4 \pm 12.9^{c}$ & $58.5 \pm 18.2^{d}$ & $34.9 \pm 1.7^{d}$ & N.D & N.D ${ }^{e}$ & N.D & N.D \\
\hline
\end{tabular}

N.D not detected

The same lowercase letters in each row are not significantly different from the residue of $\mathrm{ClO}_{2}$ in the seeds after sequential presoaking and $\mathrm{ClO}$ treatment with $p<0.05$ according to Tukey's test 
were not significantly different from those of untreated seeds. Moreover, the germination rates of tatsoi and alfalfa seeds on the first day of germination after treatment with $\mathrm{ClO}_{2}$ were higher than those of untreated seeds by $37.7 \%$ and $8.0 \%$, respectively. These results implied that $\mathrm{ClO}_{2}$ treatment after soaking does not have a significantly adverse effect on the seed germination rate.

\section{Determination of residue of $\mathrm{ClO}_{2}$}

As $\mathrm{ClO}_{2}$ effectively inhibited the growth of pathogenic E. coli and Salmonella spp., it was necessary to confirm if $\mathrm{ClO}_{2}$ remained in the sprouts. The residue of $\mathrm{ClO}_{2}$ in nine kinds of sprouts for 3 days was determined (Table 3 ). The mean of $\mathrm{ClO}_{2}$ residues in various seeds ranged from 0 to $196 \mathrm{mg} \mathrm{kg}^{-1}$ after treatment. There were significant differences $(p<0.05)$ in $\mathrm{ClO}_{2}$ residues among types of seeds. The highest $\mathrm{ClO}_{2}$ residue was from alfalfa seeds and the lowest was from red radish seeds $(p<0.05)$. However, $\mathrm{ClO}_{2}$ was not presented in any sprout after 3 days of cultivation.

\section{Discussion}

In the present study, $200 \mathrm{ppm} \mathrm{ClO}_{2}$ treatment for $1 \mathrm{~h}$ resulted in 1.22 to $1.61 \log \mathrm{CFU} \mathrm{g}{ }^{-1}$ reductions of pathogenic E. coli and Salmonella spp. in unsoaked alfalfa seeds. A higher reduction of E. coli and Salmonella spp. resulted from presoaked alfalfa seeds compared to unsoaked seeds in the present study (2.07 and $1.47 \log \mathrm{CFU} \mathrm{g}{ }^{-1}$ reduced more than unsoaked, respectively). Taormina et al. [9] also reported that exposure to $200 \mathrm{ppm} \mathrm{ClO}_{2}$ for 3 to $10 \mathrm{~min}$ resulted in only 1.0 to $2.0 \log$ reduction of E. coli $\mathrm{O} 157: \mathrm{H} 7$ in alfalfa seeds. This means that $\mathrm{ClO}_{2}$ treatment alone may be inadequate for controlling foodborne pathogens on seeds. Taormina et al. [9] concluded that this is due to cracks and crevices harboring pathogens on alfalfa seed surfaces, where these chemicals could not sufficiently contact the pathogens. Thus, we investigated the synergic effect of presoaking and $\mathrm{ClO}_{2}$ treatment on the reduction of those bacteria in alfalfa seeds. Previous authors also agreed with us on the effectiveness of presoaked to the main treatment in their study [19].

To explain this issue, Delaquis et al. [21] performed a microscopic examination of alfalfa seeds and reported that although the seed surface is relatively smooth the stem scar is relatively porous with areas capable of harboring pathogens, thus affording protection to hidden bacterial cells. In addition to their topographic complexity, the surface of alfalfa seeds is covered with a waxy cuticle (cutin), lowering their water wettability. Charkowski et al. [22], however, mentioned that, by presoaking seeds in water for a certain period of time, water is believed to permeate the seed coat, causing bacteria trapped in cracks, crevices, or other discontinuities to be released, and the released bacteria are inactivated by $\mathrm{ClO}_{2}$ easily.

This study also presented the optimum treatment condition of $\mathrm{ClO}_{2}$ as a sanitizer agent after soaking of alfalfa seeds. As $\mathrm{ClO}_{2}$ concentration and treatment time increased, significant differences $(p<0.05)$ were observed in the inactivation levels of pathogenic E. coli and Salmonella spp. When presoaked alfalfa seeds were exposed to $200 \mathrm{ppm} \mathrm{ClO}_{2}$ for $1 \mathrm{~h}$, the populations of pathogenic E. coli and Salmonella spp. was significantly decreased by 4.00 and $4.26 \log$ CFU g g ${ }^{-1}$, respectively $(p<0.05)$. In addition, these pathogens were completely inactivated in alfalfa seeds inoculated with $4 \log$ CFUg- 1 and the pathogens were not detected after sprouting. However, untreated seeds contained pathogens at low levels, such as $2 \log \mathrm{CFU} \mathrm{g}{ }^{-1}$, and subsequent sprouting resulted in populations of E. coli and Salmonella spp. of 7.5 and 7.35 $\log \mathrm{CFU} \mathrm{g}{ }^{-1}$ after 3 days sprouting, respectively. In a previous study, although the populations of E. coli $\mathrm{O} 157: \mathrm{H} 7$ and Salmonella spp. were reduced by more than $5 \mathrm{log}$ CFU g ${ }^{-1}$ in alfalfa seeds using dryheat treatment, E. coli O157:H7 and Salmonella spp. increased to 5 to $7 \log$ CFU g ${ }^{-1}$ after 3 days of sprouting. These studies emphasized the importance of the elimination of foodborne pathogens on sprout seeds to prevent or greatly minimize foodborne diseases associated with sprout consumption.

As the optimal condition was applied to various seeds, E. coli and Salmonella spp. were completely inactivated on all seeds inoculated individually with 2 and $4 \log$ $\mathrm{CFUg}^{-1}$, and these pathogens were not also detected after sprouting, except radish seeds. Differences in the pathogen reduction levels may be due to the differences in the surface characteristics and size of seeds. Bari et al. [23] reported that dry heat treatment at $50{ }^{\circ} \mathrm{C}$ for $17 \mathrm{~h}$ could reduce the numbers of E. coli $\mathrm{O} 157: \mathrm{H} 7$ in alfalfa seeds to below the detection limit, whereas $24 \mathrm{~h}$ treatment was required for radish seeds. Fransisca et al. [24] found that several sanitizers, including $\mathrm{Ca}(\mathrm{OCl})_{2}$ and malic acid, reduced $E$. coli O157:H7 more in alfalfa seeds than in radish seeds. The $\mathrm{Ra}$ (arithmetic mean roughness) value of radish seeds $(6.08 \mathrm{~mm})$ was higher than that of alfalfa seeds $(0.56 \mathrm{~mm})$, and generally, a negative correlation existed between the Ra values of seeds and microbial reduction by sanitizer treatment [24]. It is supposed that the size of the seeds also affects the reduction of $E$. coli and Salmonella spp. Radish seeds are more than $2.2 \mathrm{~mm}$ but less than $1.0 \mathrm{~mm}$, which is different from crimson clover seeds (data not shown). The larger the size of seeds, the more areas capable of harboring pathogens occurred in seeds. Thus, chemicals could not sufficiently contact the pathogens in radish seeds with a rough surface and large size. Although the efficacy of $\mathrm{ClO}_{2}$ treatment against a number of viral and bacterial pathogens 
and/or rot organisms is not generally questioned, germination rate and chemical residues are concerns due to $\mathrm{ClO}_{2}$ treatment. It is important to monitor the residual levels of $\mathrm{ClO}_{2}$. In the present experiments, there were no differences $(p>0.05)$ in germination between untreated and $200 \mathrm{ppm} \mathrm{ClO}_{2}$-treated seeds, consistent with previous studies using gaseous or aqueous $\mathrm{ClO}_{2}$. This results implied that the combination of presoaking and $\mathrm{ClO}_{2}$ treatment does not have an effect on the germination of seeds.

In addition, the final product of sprouts may be safe because $\mathrm{ClO}_{2}$ was not detected after sprouting for 3 days. Smith et al. [25] revealed that significant quantities of chlorate residues were formed from $\mathrm{ClO}_{2}$ treatment of seeds, but these residues were removed during the sprouting process. Moreover, chlorate residues that possibly remained on seeds might have been transformed by bacterial action during the sprouting process as chlorate residues are prone to biodegradation in biotic environments conducive to bacterial growth. This is in harmony with consumer preference for safe fresh produce [26].

In conclusion, most sprout farms in Korea use sanitizers before $5 \mathrm{~h}$ soaking. However, data presented here suggested that sequential $5 \mathrm{~h}$ presoaking and $200 \mathrm{ppm} \mathrm{ClO}_{2}$ treatment for $1 \mathrm{~h}$ is more effective to eliminate E. coli and Salmonella spp. from sprout seeds without decreasing the germination rate. For industrial applications, the efficacy of the decontamination procedure developed in this study should be validated using commercial-scale sprout production practices.

\section{Acknowledgements}

This study was carried out with the support of the Research Program for Agricultural Science \& Technology Development (Project No. 01357801) and the National Institution of Agricultural Science, Rural Development Administration, Republic of Korea.

\section{Authors' contributions}

NBH performed the experiment, data analysis and interpretation, and wrote the fnal manuscript. WRP analyzed data and drafted the manuscript. BHY and DCS performed the experiment, data analysis. WIK and HJK contributed materials and editorials. SHH and SRK supervised the project and revised the fnal manuscript. All authors read and approved the final manuscript.

\section{Availability of data and materials}

Datasets used and/or analyzed during the current study that are not included in the manuscript are available from the corresponding author on reasonable request.

\section{Competing interests}

The authors declare that they have no competing interests.

\footnotetext{
Author details

${ }^{1}$ Microbial Safety Team, Department of Agro-Food Safety \& Crop Protection, National Institute of Agricultural Sciences (NAS), Rural Development Administration (RDA), Wanju 55365, Republic of Korea. ${ }^{2}$ Department of Animal Science and Institute of Milk Genomics, Chonbuk National University, Jeonju 54896, Republic of Korea. ${ }^{3}$ Department of Agricultural Chemistry and Food Science \& Technology, Gyeongsang National University, Jinju 52828, Republic of Korea. ${ }^{4}$ Crop Science Division, National Institute of Crop Sciences (NICS), Rural Development Administration (RDA), Wanju 55365, Republic
}

of Korea. ${ }^{5}$ Research Policy Division, Research Policy Bureau, Rural Development Administration (RDA), Jeonju 54875, Republic of Korea. ${ }^{6}$ Laboratory of Enzyme and Protein Technology, Institute of Biotechnology, Hue University, Hue 530000, Vietnam.

Received: 9 May 2020 Accepted: 2 September 2020

Published online: 10 September 2020

\section{References}

1. Bari ML, Inatsu Y, Isobe S, Kawamoto S (2008) Hot water treatments to inactivate Escherichia coli O157:H7 and Salmonella in mung bean seeds. J Food Prot 71(4):830-834. https://doi.org/10.4315/0362-028x-71.4.830

2. Soengas P, Sotelo T, Velasco P, Cartea ME (2011) Antioxidant properties of Brassica vegetables. Funct Plant Sci Biotechnol 5(2):43-55

3. National Advisory Committee on Microbiological Criteria for Foods (NACMCF) (1999) Microbiological safety evaluations and recommendations on sprouted seed. Int J Food Microbiol 52(3):123-153. https://doi. org/10.1016/s0168-1605(99)00135-x

4. Watanabe Y, Ozasa K, Mermon JH, Griffin PM, Masuda K, Imashuku S, Sawada T (1999) Factory outbreak of Escherichia coli O157:H7 infection in Japan. Emerg Infect Dis 5(3):424-428. https://doi.org/10.3201/eid05 03.990313

5. Bang J, Kim H, Kim H, Beuchat LR, Ryu JH (2011) Combined effects of chlorine dioxide, drying, and dry heat treatments in inactivating microorganisms on radish seeds. Food Microbiol 28(1):114-118. https://doi. org/10.1016/j.fm.2010.09.002

6. Dechet AM, Herman KM, Chen Parker C, Taormina P, Johanson J, Tauxe RV, Mahon BE (2014) Outbreaks caused by sprouts, United States, 1998-2010: lessons learned and solutions needed. Foodborne Pathog Dis 11(8):635644. https://doi.org/10.1089/fpd.2013.1705

7. Uphoff H, Hedrich B, Strotmann I, Arvand M, Bettge-Weller G, Hauri AM (2014) A prolonged investigation of an STEC-O104 cluster in Hesse, Germany, 2011 and implications for outbreak management. J Public Health 22:41-48

8. Emberland $\mathrm{K}$, Ethelberg $\mathrm{S}$, Kuusi M, Vold L, Jensvoll L, Lindstedt BA, Nygard K, Kjelsø C, Torpdahl M, Sørensen G, Jensen T, Lukinmaa S, Niskanen T, Kapperud G (2007) Outbreak of Salmonella Weltevreden infections in Norway, Danmarkand Finland associated with alfalfa sprouts, July-October 2007. Euro Surveill 12(11):389-390. https://doi.org/10.2807/ esw.12.48.03321-en

9. Taormina PJ, Beuchat LR (1999) Comparison of chemical treatment to eliminate Enterohemorrhagic Escherichia coli O157:H7 on alfalfa seeds. $J$ Food Prot 62(4):318-324. https://doi.org/10.4315/0362-028x-62.4.318

10. Lang MM, Ingham BH, Ingham SC (2000) Efficacy of novel organic acid and hypochlorite treatments for eliminating Escherichia coli O157:H7 from alfalfa seeds prior to sprouting. Int J Food Microbiol 58(1-2):73-82. https ://doi.org/10.1016/s0168-1605(00)00297-x

11. Holliday SL, Scouten AJ, Beuchat LR (2001) Efficacy of chemical treatments in eliminating Salmonella and Escherichia coli O157:H7 on scarified and polished alfalfa seeds. J Food Prot 64(10):1489-1495. https://doi. org/10.4315/0362-028x-64.10.1489

12. Montville R, Schaffner DW (2004) Analysis of published sprout seed sanitization studies shows treatments are highly variable. J Food Prot 67(4):758-765. https://doi.org/10.4315/0362-028X-67.4.758

13. Soylemez G, Brashears MM, Smith DA, Cuppett SL (2001) Microbial quality of alfalfa seeds and sprouts after a chlorine treatment and packaging modifications. J Food Sci 66(1):153-157. https://doi. org/10.1111/j.1365-2621.2001.tb15598.x

14. Beuchat $L R$, Ward TE, Pettigrew CA (2001) Comparison of chlorine and a prototype produce wash product for effectiveness in killing Salmonella and Escherichia coli 0157:H7 on alfalfa seeds. J Food Prot 64(2):152-158. https://doi.org/10.4315/0362-028x-64.2.152

15. Wade WN, Scouten AJ, McWatters KH, Wick RL, Demirci A, Fett WF, Beuchat LR (2003) Efficacy of ozone in killing Listeria monocytogenes on alfalfa seeds and sprouts and effects on sensory quality of sprouts. J Food Prot 66(1):44-51. https://doi.org/10.4315/0362-028X-66.1.44

16. Kim C, Hung YC, Brackett RE, Lin CS (2003) Efficacy of electrolyzed oxidizing water in inactivating Salmonella on alfalfa seeds and sprouts. J Food Prot 66(2):208-214. https://doi.org/10.4315/0362-028x-66.2.208 
17. Sharma RR, Demirci A (2003) Inactivation of Escherichia coli O157:H7 on inoculated alfalfa seeds with pulsed ultraviolet light and response surface modeling. J Food Sci 68(4):1448-1453. https://doi. org/10.1111/j.1365-2621.2003.tb09665.x

18. Yoon JH, Lee SY (2017) Comparison of the effectiveness of decontaminating strategies for fresh fruits and vegetables and related limitations. Crit Rev Food Sci Nutr 11:1-20. https://doi.org/10.1080/10408398.2017.13548 13

19. Neetoo $H$, Chen $H$ (2010) Pre-soaking of seeds enhances pressure inactivation of Escherichia coli O157:H7 and Salmonella spp. on crimson clover, red clover, radish and broccoli seeds. Int J Food Microbiol 137(2-3):274280. https://doi.org/10.1016/j.ijfoodmicro.2009.11.026

20. Keasler K, Paula RMD, Nilsen G, Grunwald L, Tidwell TJ (2017) Trends in oil and gas corrosion research and technologies. In: El-Sherik AM, editor. Woodhead publishing series in energy 39-562. https://doi.org/10.1016/ B978-0-08-101105-8.00007-3

21. Delaquis PJ, Sholberg PL, Stanich K (1999) Disinfection of mung bean seed with gaseous acetic acid. J Food Prot 62(8):953-957. https://doi. org/10.4315/0362-028x-62.8.953

22. Charkowski AO, Sarreal CZ, Mandrell RE (2001) Wrinkled alfalfa seeds harbor more aerobic bacteria and are more difficult to sanitize than smooth seeds. J Food Prot 64(9):1292-1298. https://doi. org/10.4315/0362-028X-64.9.1292
23. Bari ML, Nei D, Enomoto K, Todoriki S, Kawamoto S (2009) Combination treatments for killing Escherichia coli O157:H7 on alfalfa, radish, broccoli, and mung bean seeds. J Food Prot 72(3):631-636. https://doi. org/10.4315/0362-028x-72.3.631

24. Fransisca L, Feng $\mathrm{H}$ (2012) Effect of surface roughness on inactivation of Escherichia coli O157:H7 87-23 by new organic acid-surfactant combinations on alfalfa, broccoli, and radish seeds. J Food Prot 75(2):261-269. https://doi.org/10.4315/0362-028X.JFP-11-279

25. Smith DJ, Herges GR (2018) Chloroxyanion residue on seeds and sprouts after chlorine dioxide sanitation of alfalfa seed. J Agr Food Chem 66(8):1974-1980. https://doi.org/10.1021/acs.jafc.7b05953

26. Sutigoolabud P, Senoo K, Ongprasert S, Mizuno T, Tanaka A, Obata H, Hisamatsu M (2005) Decontamination of chlorate in longan plantation soils by bio-stimulation with sugar amendment. Soil Sci Plant Nutr 51(4):583-588. https://doi.org/10.1111/j.1747-0765.2005.tb00068.x

\section{Publisher's Note}

Springer Nature remains neutral with regard to jurisdictional claims in published maps and institutional affiliations.

\section{Submit your manuscript to a SpringerOpen ${ }^{\circ}$ journal and benefit from:}

- Convenient online submission

- Rigorous peer review

- Open access: articles freely available online

- High visibility within the field

- Retaining the copyright to your article

Submit your next manuscript at $\boldsymbol{\nabla}$ springeropen.com 